\title{
Plume-ridge interactions: Ridge suction versus plate drag
}

\section{Fengping Pang ${ }^{1}$, Jie Liao ${ }^{1,2,3}$, Maxim D. Ballmer ${ }^{4}$, Lun Li ${ }^{1,2,3}$}

${ }^{1}$ School of Earth Sciences and Engineering, Sun Yat-Sen University, Guangzhou 510275, China

${ }^{2}$ Guangdong Provincial Key Lab of Geodynamics and Geohazards, Guangzhou 510275, China

${ }^{3}$ Southern Marine Science and Engineering Guangdong Laboratory (Zhuhai), Zhuhai 519000, China

${ }^{4}$ Department of Earth Sciences, University College London, London, United Kingdom

Correspondence: Jie Liao (liaojie5@ mail.sysu.edu.cn)

\section{Abstract}

Mid-ocean ridges and mantle plumes are two attractive windows to allow us to get a glimpse of mantle structure and dynamics. Dynamical interaction between ridge and plume processes have been widely proposed and studied, particularly in terms of ridge suction. However, the effects of plate drag on plumes and plume-ridge interaction remains poorly understood. Quantification of suction versus plate drag between ridges and plumes remains absent. Here we use 2D thermomechanical numerical models to study the plume-ridge interaction, exploring the effects of (i) the spreading rate of ridge, (ii) the plume radius, and (iii) the plume-ridge distance systematically. Our numerical experiments suggest two different geodynamic regimes: (1) plume motion prone to ridge suction is favored by strong buoyant mantle plume and short plume-ridge distance, and (2) plume migration driven by plate drag is promoted by fast-ridge spreading rate. Our results highlight fast-spreading ridges exert strong plate 
https://doi.org/10.5194/se-2022-20

Preprint. Discussion started: 16 February 2022

(C) Author(s) 2022. CC BY 4.0 License.

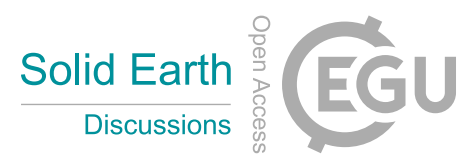

(c) (1)

21 dragging force, rather than suction on plume motion, which sheds new light on the natural observations

22 of plume absence along the fast-spreading ridges, such as the East Pacific Rises.

23

24 


\section{Introduction}

Mid-ocean ridges (MORs) and hotspots are two main regions for deep material recycling to the surface of the Earth. However, these two units are not always isolated but showing strong interactions in some cases, termed as plume-ridge interaction (Morgan, 1971). Of up to 50 mantle plumes revealed by seismic tomography (French and Romanowicz, 2015; Montelli et al., 2004), more than 20 plumes are found to be associated with nearby ridges (Ito et al., 2003). The plume-ridge interaction is manifested by some geophysical and geochemical anomalies along ridge axis, e.g., high mantle potential temperature (Dalton, 2014), enriched radiogenic isotopes towards ridge axis (Cushman et al., 2004; Douglass and Schilling, 1999; Yang et al. 2017), and the lineament of volcanoes on the seafloor (Geissler et al., 2020; Lénat and Merle, 2009). Besides, plumes may also promote migration of MORs (Müller and Roest, 1998; Mittelstaedt et al., 2008, 2011; Whittaker et al., 2015), which was evidenced by successive ridge jumps towards mantle plumes, e.g., Hawaii, Amsterdam (Li and Detrick, 2003). The major factors affecting ridge suction on plumes includes ridge spreading rate, plume buoyancy flux and their spatial distance (Fig. 1b; François et al., 2018; Kincaid et al., 1996; Ribe et al., 1995; Ribe, 1996; Sleep, 1997). Most plume-ridge interaction systems links to slow-spreading ridges $(<2.5$ cm/yr; Gerya, 2012) and small mantle plumes and short plume-ridge distances. However, systematical studies investigating these parameters remain scarce regarding the effects of these parameters on the behavior of plume-ridge interaction.

Additionally, among the interacted systems, plumes interacting with ridges appear more abundant near the Mid-Atlantic ridge (MAR), comparing to the East Pacific Rise (EPR). The reason attributed to such a distribution is still enigmatic. A previous study (Jellinek et al., 2003) proposed that fastspreading ridges exert strong suction on plumes and attract the surrounding plumes entirely from deep 
depth (Fig. 1c), resulting in the absence of plumes adjacent to the EPR (Fig. 1a). However, a series of spatiotemporal volcanic chains with linear progressing age are found in different Oceans (Jackson et al., 2010). Not only do MORs suck the proximal plumes into the spreading center (Koptev et al., 2015; Niu, 2014), but they can conversely drag mantle plumes away. Therefore, an alternative explanation to the plume absence along the fast-spreading ridges could be plate drag, i.e., fast-spreading ridges push away the surrounding plumes. Plate drag, in contrast to suction, however, remains poorly studied. Moreover, either ridge suction or plate drag acts on mantle plumes remains an intriguing question.

This study utilizes two-dimensional (2D) numerical models to investigate the process of plumeridge interaction, with emphasizing on the effects of model parameters on the ridge suction versus plate drag. We demonstrate that ridge suction and plate-drag on plumes are influenced by the distinctive parameters. Slow-spreading rate, short distance and large plume radius promote ridge suction, whereas the opposite effects of these parameters favor pushing plumes away. We further propose that fast-spreading ridges exerts strong dragging on plumes due to the large shear force along the base of the oceanic plate. This process of plate drag, instead of ridge suction, on plume may support the explanation of the plume-ridge interaction absence along the East Pacific Rise. 
(a)

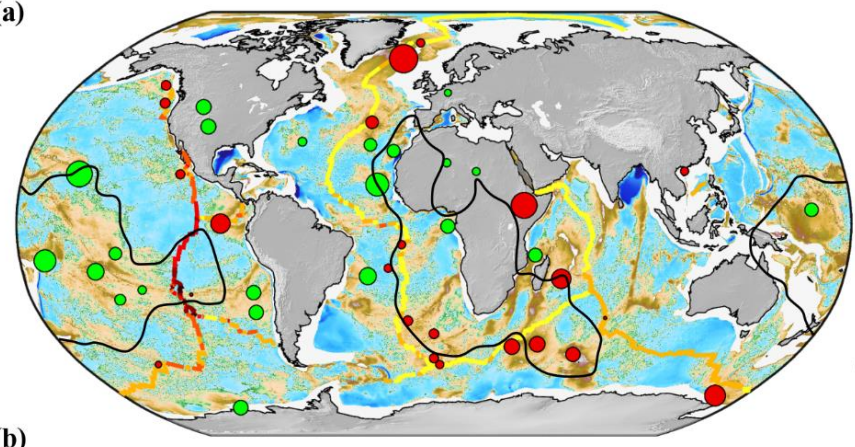

(b)
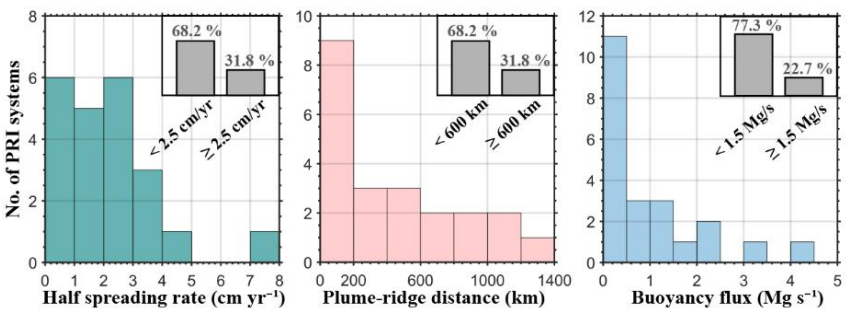

plume interacting with a ridge

plume not interacting with a ridge
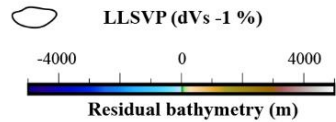

$\begin{array}{lllllll}0 & 1 & 2 & 3 & 4 & 5 & 6\end{array}$

Half spreading rate $\left(\mathrm{cm} \mathrm{yr}^{-1}\right)$

(c)

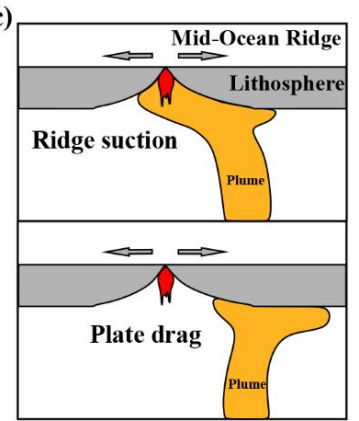

Figure 1. Global plume-ridge interaction systems. (a) Residual bathymetry of the ocean basins (Straume et al., 2019). Mid-ocean ridges are painted in color solid lines corresponding to halfspreading rate. Plumes not interacting with a ridge are shown by green circles, and hotspots linked to ridges are in red dots (Ito et al., 2003), and size refers to the plume buoyancy flux from Hoggard (2020). Black lines denote the regions of two LLSVPs under the South Africa and Pacific Ocean (Torsvik et al., 2006). (b) Histograms of influential factors of plume-ridge interaction systems. Half spreading rate and plume-ridge distance come from Gplates (Müller et al., 2016; Whittaker et al., 2015). Plume-ridge interaction systems link to slow-spreading ridge and small mantle plumes and short plume-ridge distance. (c) Sketches of ridge suction and plate drag mode proposed, respectively. 
(a)

Free slip / Cooling at $0^{\circ} \mathrm{C}$
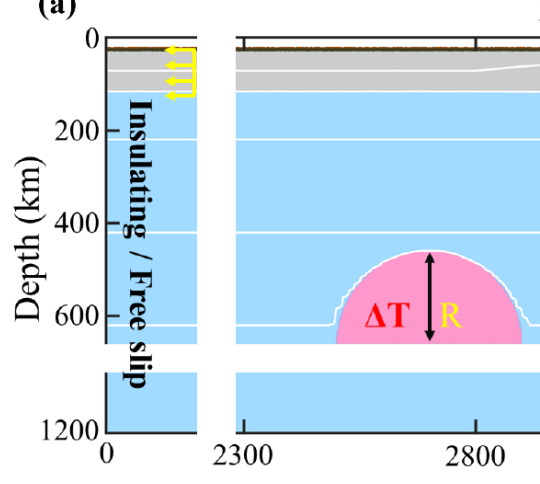

Free slip / Co
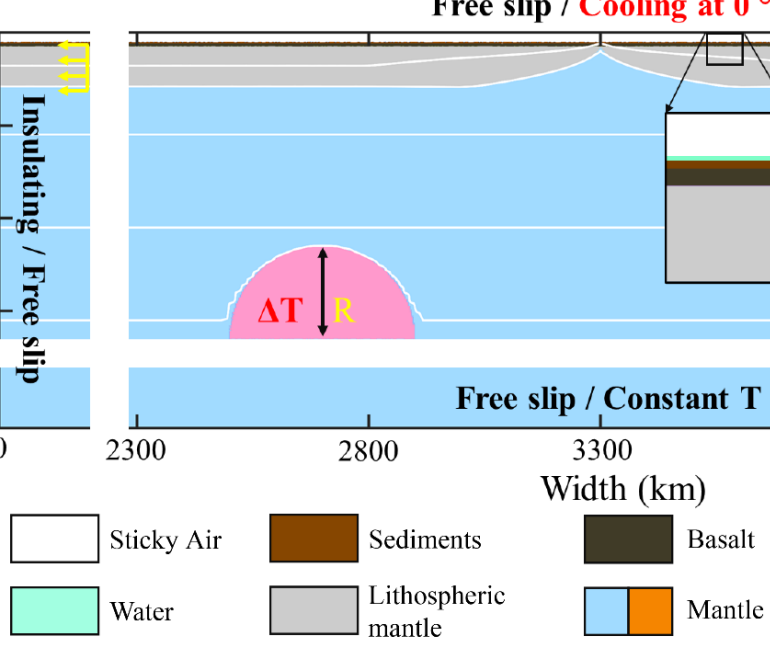

Free slip / Constant T

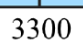

Width (km)

b)
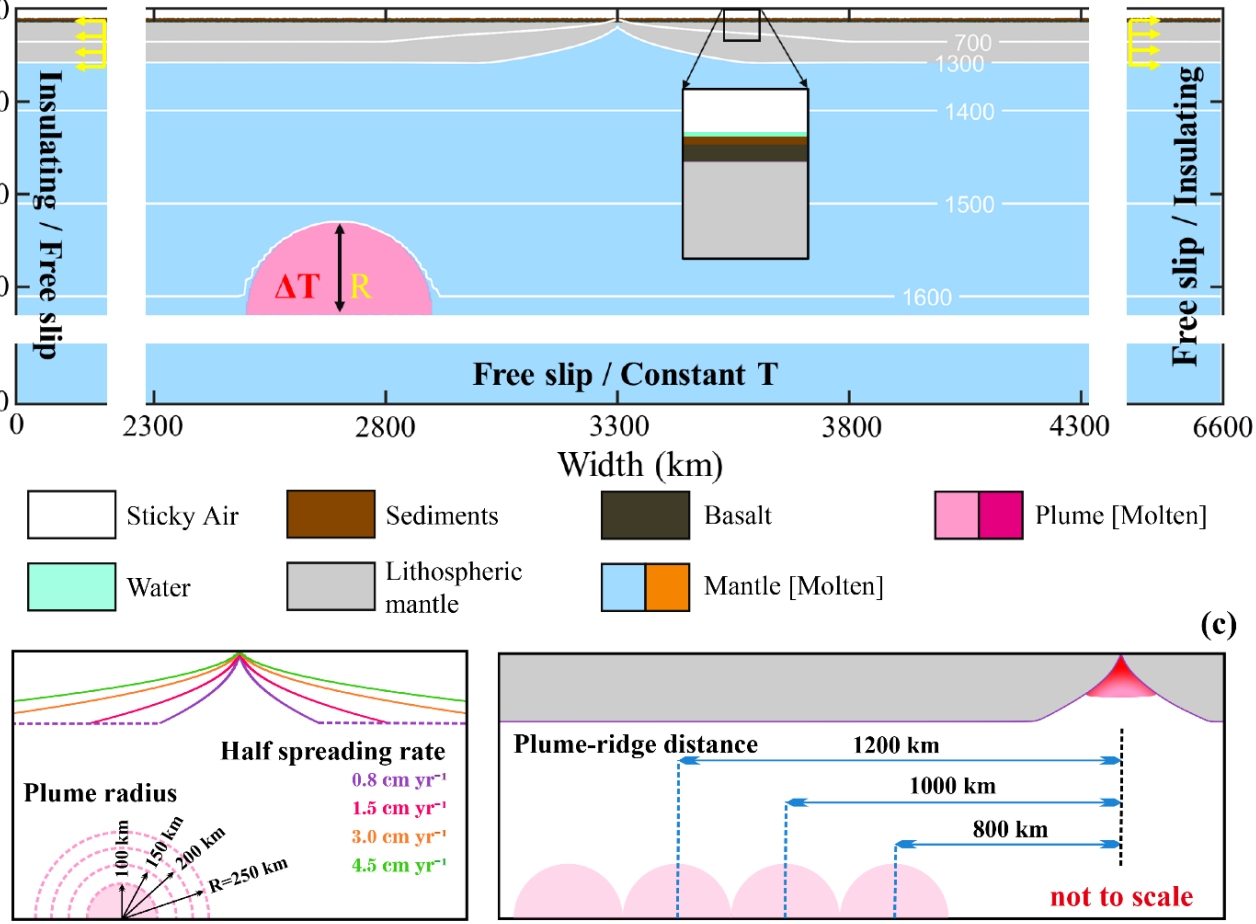

Figure 2. Model setup. (a) Initial composition and boundary conditions. A 50-Myrs-old mid-ocean

ridge sets in the middle of the model based on half-space cooling temperature structure. A thermal and

chemical anormal mantle plume locates at $660 \mathrm{~km}$. Colored boxes refer to the initial rock type, and

corresponding newly formed molten rock types are also show in the rock boxes. (b) Initial tested ridge and plume configurations. (c) Initial tested plume-ridge distances.

\section{Numerical modelling}

\subsection{Modelling methods}

We conduct simulations by utilizing the 2D thermo-mechanical coupled codes I2VIS, which is based on staggered finite difference method combined with marker-in-cell techniques (Gerya and Yuen, 
2003, 2007). This modeling framework uses both Eulerian grid and fully randomly-distributed Lagrangian markers to jointly solve equations of conservation of mass, momentum and energy (Eq. (1)-(3), respectively):

$$
\begin{gathered}
\nabla \cdot \vec{v}=0 \\
\frac{\partial \sigma_{i j}^{\prime}}{\partial x_{j}}-\frac{\partial P}{\partial x_{i}}+\rho g_{i}=0 \\
\rho C_{p}\left(\frac{D T}{D t}\right)=-\nabla \cdot \vec{q}+H_{r}+H_{a}+H_{s}+H_{l}
\end{gathered}
$$

where $v$ refers to the velocity, $\sigma_{i j}^{\prime}$ the deviatoric stress tensor, $P$ the pressure, $\rho$ the density, $g$ the gravity acceleration, $\frac{D}{D t}$ the Lagrangian time derivative, $C_{\boldsymbol{p}}$ the heat capacity, and $\vec{q}$ the heat flux. Additionally, $H_{r}, H_{a}, H_{s}$, and $H_{l}$ are the radioactive, adiabatic, shear, and latent heat productions, respectively.

We employ the non-Newtonian visco-plastic rheology (Gerya and Yuen, 2007) in the models. The viscous rheology depends on the stress rate, temperature and pressure, and can be expressed by the effective viscosity of the material (Eq. (4)).

$$
\frac{1}{\eta_{\text {eff }}}=\frac{1}{\eta_{\text {diff }}}+\frac{1}{\eta_{\text {disl }}}
$$

in which $\eta_{\text {diff }}$ and $\eta_{\text {disl }}$ are the diffusion and dislocation creep viscosity respectively, and can be further computed as Eq. (5) and Eq. (6):

$$
\begin{aligned}
& \eta_{\text {diff }}=\frac{1}{2} A \sigma_{\text {crit }}^{1-n} \exp \left(\frac{P V_{a}+E_{a}}{R T}\right) \\
& \eta_{\text {disl }}=\frac{1}{2} A^{\frac{1}{n}} \dot{\varepsilon}_{I I}^{\frac{1-n}{n}} \exp \left(\frac{P V_{a}+E_{a}}{n R T}\right)
\end{aligned}
$$

where $P$ is the pressure, $T$ is the temperature, $\dot{\varepsilon}_{I I}$ is the second invariant of the strain rate tensor, $\sigma_{\text {crit }}$ is the diffusion-dislocation creep transition stress, and $A, E_{a}, V_{a}$, and $\mathrm{n}$ are strain rate pre-exponential factor, activation energy, activation volume, and stress exponent, respectively. The plastic behavior is described by the Drucker-Prager yield criterion (Byerlee, 1978; Ranalli, 1995) according to Eq. (7): 


$$
\sigma_{y}=C+P \varphi
$$

in which $\sigma_{y}$ as the yield stress, $C$ the rock cohesion and $\varphi$ the effective friction coefficient. The effective viscosity of rocks is thus constrained by all abovementioned rheological laws in our models.

Partial melting, melt extraction and percolation to the base of the crust are also considered and completed in a simplified way (Gerya, 2013). In the model, the melt extraction and percolation is modeled indirectly and considered as an instantaneous process. We calculate the melt fraction (i.e. without melt extraction), $M_{0}$, of the mantle based on a nonlinear parameterized batch melting model of Katz (2003). For other lithologies, the melt fraction $\left(M_{0}\right)$ are assumed to increase linearly with temperature and are calculated as Eq. (8):

$$
\begin{gathered}
M_{0}=0 \text { when } T \leq T_{\text {solidus }} \\
M_{0}=\frac{\left(T-T_{\text {solidus }}\right)}{\left(T_{\text {liquidus }}-T_{\text {solidus }}\right)} \text { when } T_{\text {solidus }}<T<T_{\text {liquidus }} \\
M_{0}=1 \text { when } T \geq T_{\text {liquidus }}
\end{gathered}
$$

Where $T_{\text {solidus }}$ and $T_{\text {liquidus }}$ are the solidus and liquidus temperature of different rock type, respectively. The amount of extracted melt during the evolution of each experiment is traced by the lagrangian markers (Gerya, 2013). The total amount of melt, M, for every marker takes into the amount of previously extracted melt according to Eq. (9):

$$
M=M_{0}-\Sigma_{n} M_{\text {ext }}
$$

where $\Sigma_{n} M_{\text {ext }}$ refers to the total melt fraction extracted during the previous $n$ melt extraction timesteps. Rocks are assumed non-molten if the extracted melt fraction $\left(\Sigma_{n} M_{\text {ext }}\right)$ surpasses the standard melt fraction $\left(\Sigma_{n} M_{\text {ext }}>M_{0}\right)$. The modeled melt is extracted upwards when the total amount of melt $M$ exceeds the given extraction threshold $M_{\min }=2 \mathrm{wt} \%$. Hence, the extracted melt is assumed to move vertically instantaneously from the molten source and then added to the bottom of 
the crust.

\subsection{Model setup}

The initial model dimensions are set as $6600 \times 1200 \mathrm{~km}$, with a grid of $501 \times 301$ computational nodes in length and depth, respectively (Fig. 2). We use a variable grid spacing, so as to reach a higher grid resolution in the middle part of the domain where the plume-ridge interaction would happen. The model consists of a $20 \mathrm{~km}$ thick sticky air layer fitting crustal surface deformation, an oceanic lithosphere and asthenosphere till depth of $660 \mathrm{~km}$. To reproduce the oceanic lithosphere, we choose a typical layered model from the uppermost mantle to the surface, and the crustal part of this lithosphere is composed of a water level $(2 \mathrm{~km})$, a sediment layer $(1.5 \mathrm{~km})$, a basalt layer $(7.5 \mathrm{~km})$. The oceanic lithosphere and asthenosphere in the model are both modelled as dry olivine (the different colors for the mantle lithosphere and asthenosphere in the figures of this paper are only for better visualization). Besides, a 50-Myrs-old mid-ocean ridge is set on central part of the lithosphere, splitting the model domain into two parts. At the depth of $660 \mathrm{~km}$, a 200-km-wide semicircular plume is located on the left of model domain, corresponding to the onset of plume-ridge interaction from the mantle transition zone. Detailed rock parameters are listed in Tabel 1.

The thermal conditions of the top and bottom boundaries are fixed at 273 and $2513 \mathrm{~K}$, respectively. The left and right boundaries are both insulating, with no external heat flow across them. The temperature configuration of the oceanic lithosphere is interpolated with a linear gradient constrained by constant temperatures of 273 and $1573 \mathrm{~K}$ at the top and bottom of the lithosphere. Below the oceanic lithosphere, an adiabatic temperature gradient of $0.5 \mathrm{~K} \mathrm{~km}^{-1}$ is applied. In terms of ridge, the thermal structure and thickness of the lithosphere are calculated by the infinite half-space cooling formulation 
151 (Turcotte and Schubert, 2014). The hot plume is set an excess temperature of $250 \mathrm{~K}$ to trigger a

152 thermal-compositional plume rising from the model box. All the velocity boundaries are free slip boundaries. An additional velocity is imposed on both sides of the ridge to represent the half spreading rate.

155

Tabel 1. Rock physical properties used in the numerical models.

\begin{tabular}{|c|c|c|c|c|c|}
\hline Parameters & Sediments & Ocean Crust & Mantle & Plume & Reference $^{\mathrm{a}}$ \\
\hline Flow law & Wet quartz & Basalt & Dry olivine & Wet olivine & \\
\hline Preexponential factor $A\left(\mathrm{~Pa}^{\mathrm{n}} \mathrm{s}\right)$ & $1.97 \times 10^{17}$ & $4.80 \times 10^{22}$ & $3.98 \times 10^{16}$ & $5.01 \times 10^{20}$ & 1 \\
\hline Activation energy $E_{a}\left(\mathrm{KJ} \mathrm{mol}^{-1}\right)$ & 154 & 238 & 532 & 470 & 1 \\
\hline Activation volume $V_{a}\left(\mathrm{~J} \mathrm{bar}^{-1} \mathrm{~mol}^{-1}\right)$ & 0 & 0 & 1 & 0.8 & 1 \\
\hline Exponent $n$ & 2.3 & 3.2 & 3.5 & 4 & 1 \\
\hline Cohesion $C(\mathrm{~Pa})$ & $2 \times 10^{7}$ & $2 \times 10^{7}$ & $2 \times 10^{7}$ & $2 \times 10^{7}$ & 1 \\
\hline Effective friction coefficient $\varphi$ & $0.6 / 0.3$ & $0.6 / 0.3$ & $0.6 / 0.3$ & $0.6 / 0.3$ & 1 \\
\hline Density $\rho\left(\mathrm{Kg} \mathrm{m}^{-3}\right)$ & 2600 & 3000 & 3300 & 3270 & 2 \\
\hline Radioactive heating $H_{r}\left(\mathrm{~W} \mathrm{~m}^{-3}\right)$ & $2 \times 10^{-6}$ & $2.2 \times 10^{-7}$ & $2.2 \times 10^{-8}$ & $2.5 \times 10^{-8}$ & 2 \\
\hline
\end{tabular}

a: 1-(Ranalli, 1995), 2-(Turcotte and Schubert, 2014)

Other physical parameters used for all rocks include: gas constant $R=8.314 \mathrm{~J} \mathrm{~K}^{-1} \mathrm{~mol}^{-1}$, thermal expansion $\alpha=3 \times 10^{-5} \mathrm{~K}^{-1}$, compressibility $\beta=1 \times 10^{-11} \mathrm{~Pa}^{-1}$, heat capacity $C p=1000 \mathrm{~J} \mathrm{~kg}^{-1} \mathrm{~K}^{-1}$. 


\section{Model Results}

We conduct a series of numerical experiments to investigate ridge suction versus plate drag acts on plumes. The effect of three major model parameters (i.e., the spreading rate of mid-ocean ridge, the plume radius, and the plume-ridge distance) has been systematiclly studied. The typical dynamic evolution of ridge suction and plate drag on plumes are demonstrated.

\subsection{Ridge suction dominated model evolution}

In ridge suction dominated models, the rising plume flows toward the spreading ridge as a result of ridge suction, and the typical model evolution is shown in Fig. 3 (the major model parameters used in this case are: the half spreading rate of $8 \mathrm{~mm} \mathrm{yr}^{-1}$, the plume radius of $200 \mathrm{~km}$, and the off-axis distance of $800 \mathrm{~km}$ ). In the early plume head stage, the buoyant mantle plume rises up rapidly in a mushroom-like shape and thus imposes dynamic stresses at the base of the overriding oceanic plate, leading to significant surface uplift. (Figs.3a-b). The ascending plume experiences intensive decompression melting along the base of the overriding plate, and due to the dynamic overpressure, spreads laterally, forming two branches that flow in opposite directions with uplifted elevation (Fig. 3c). Along with plume spreading, the overriding plate begins to drag both plume branches away from the ridge. On the other hand, plate divergence at the MOR creates a dominant suction effect. As a consequence, the two branches evolve asymmetrically: the right branch that flows toward the ridge axis is more vigorous than the left branch, and the plume tail is also tilted towards the spreading center (Figs. 3c-e).

The mantle flow vertical velocity profiles further demonstrate the dominant effect of ridge suction on plume head spreading. Figure $3 \mathrm{f}$ shows that plume flow is faster towards the spreading ridge than away from it. The velocity profiles elucidate dominant Poiseuille flow, with the maximum flow 
velocities in the middle of the flowing layer, decreasing upwards and downwards. Such velocity profiles are well consistent with the anisotropy observation at the Reunion plume (Barruol et al. 2019). The overriding plate moves slower than the ponding plume, and hence actually slows down the spreading plume branches. Without suction effect from the spreading center, the left plume branch flows out much slower than the right branch.

(a)

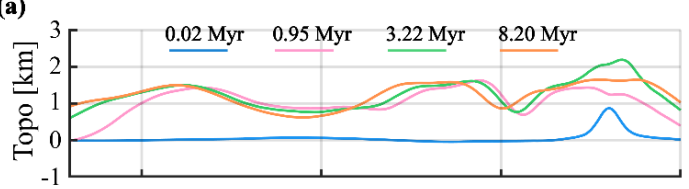

(b)

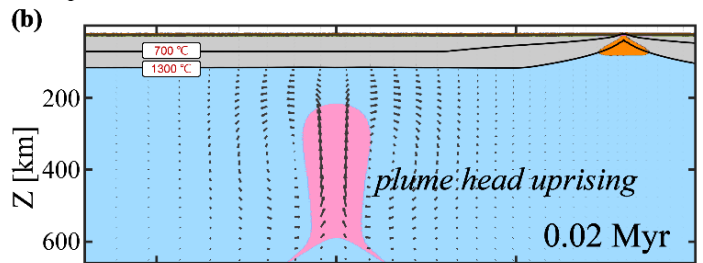

(c)

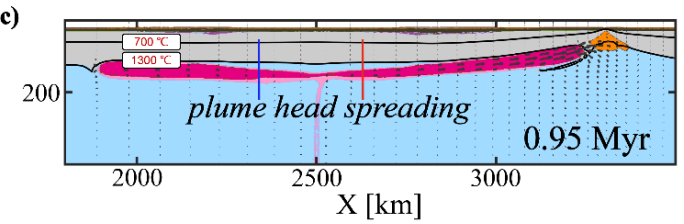

(d)

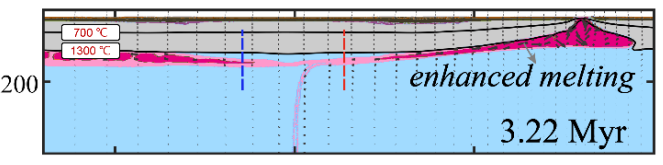

(e)

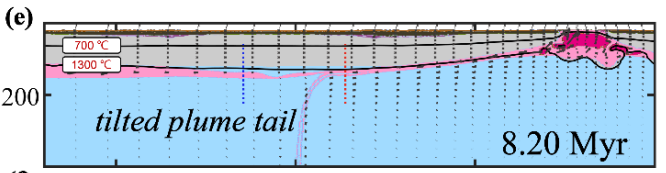

(f)

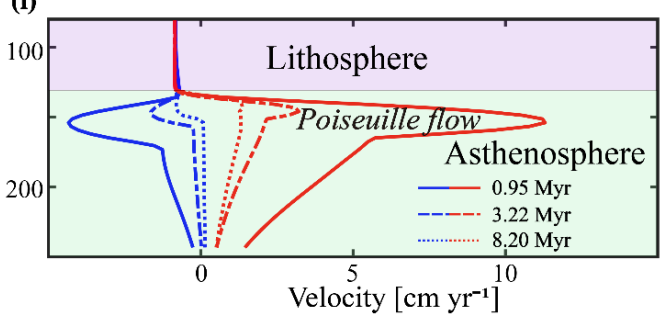

Figure 3. Reference model evolutions of ridge suction on plume flow. (a) topography evolutions along the flow path of selected snapshots. (b-e) snapshots of reference suction dominated model in compositional domain. Solid, dash and dotted lines are the velocity profiles of plume branches $100 \mathrm{~km}$ aside the plume stem and plot in (f). (f) mantle flow velocity structure evolutions of ridge-ward and dragged plume domains marked in red and blue lines, respectively.

A large amount of plume material is entrained towards the spreading center, ponding underneath the ridge axis, and significantly affecting the ridge dynamics. The entrainment of hot plume material increases the temperatures beneath the ridge, promotes decompression melting and boosts surface heat 
flux (Fig. 5d). The buoyant mantle plume then strongly weakens the overlying oceanic plate and changes the stress state of the overlying oceanic plate, forming a series of tension cracks due to the forced uplift (Figs. 5c,d). Magma extracts to the surface through these cracks, especially in areas that lithosphere is thin and weak. As such, a large amount of plume material beneath the thinner lithosphere near the mid-ocean ridge is extracted to the surface, which depends on the melt temperature and pressure. Such melt extraction via separated tension cracks may imply the formation of near-linear volcanic ridges.

\subsection{Plate-drag dominated model evolution}

In plate-drag dominated models, the rising mantle plume is simulated to flow away from the spreading ridge and is dominantly driven by the drag of the moving plate (typical model evolution is shown in Fig. 4). This representative model has a similar configuration as the ridge suction dominated model (shown in Fig. 3) except with a smaller radius $(100 \mathrm{~km})$ and interacts with a faster spreading center (half spreading rate: $45 \mathrm{~mm} \mathrm{yr}^{-1}$ ). The ascending plume head spreads out similarly and interacts with the overriding oceanic plate. The largest surface uplift is produced above the plume head (Fig. 4a), slightly different from the previous model in which the highest surface elevation is observed on the two sides of the plume conduit (Fig. 3a). The plume head spreads laterally underneath the oceanic plate, and undergoes decompression melting (Fig. 4c). Unlike the ridge suction dominated model, in which a large portion of plume material flows towards the ridge, this model displays most plume material flowing away from the ridge owing to the dragging of plate (Figs. 4c-e).

The underlying mechanism of plate-drag is the shearing force of the spreading plate, which is further demonstrated by the plume flow velocity profiles (Fig. 4f). In the early plume head stage $(\sim 0.91$ 

at this stage. After a certain time ( $2.32 \mathrm{Myr})$, plume spreading becomes significantly slower than plate velocity, and hence plate-drag drives and controls passive plume flow. Flow mode from Poiseuille flow (i.e., active plume flow) shifts progressively to Couette flow (i.e., passive plume flow) (Fig. 4f), indicating the increasing role of plate drag on plume flow.
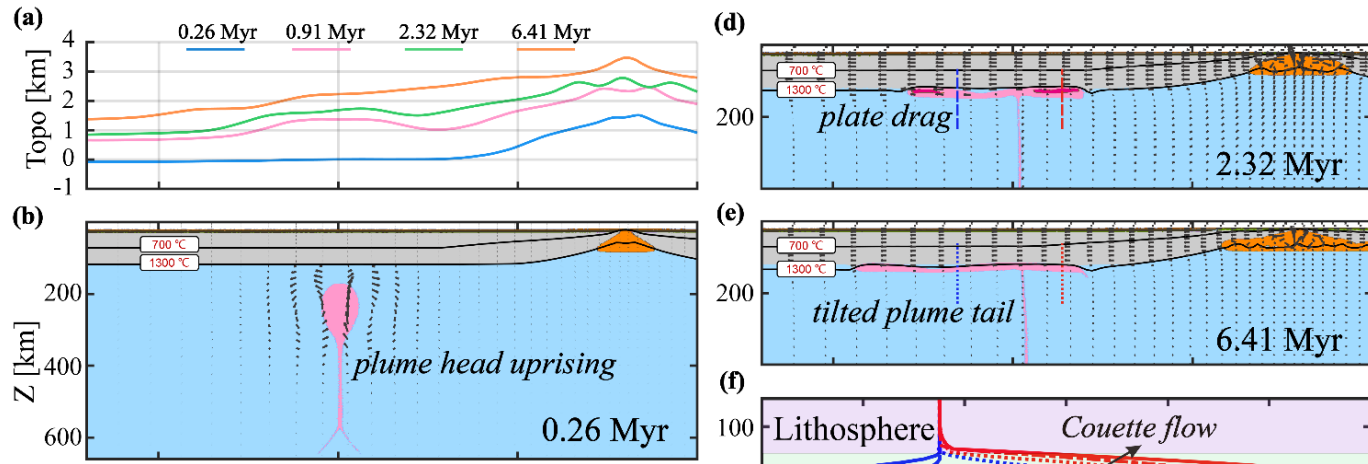

(e)

(c)
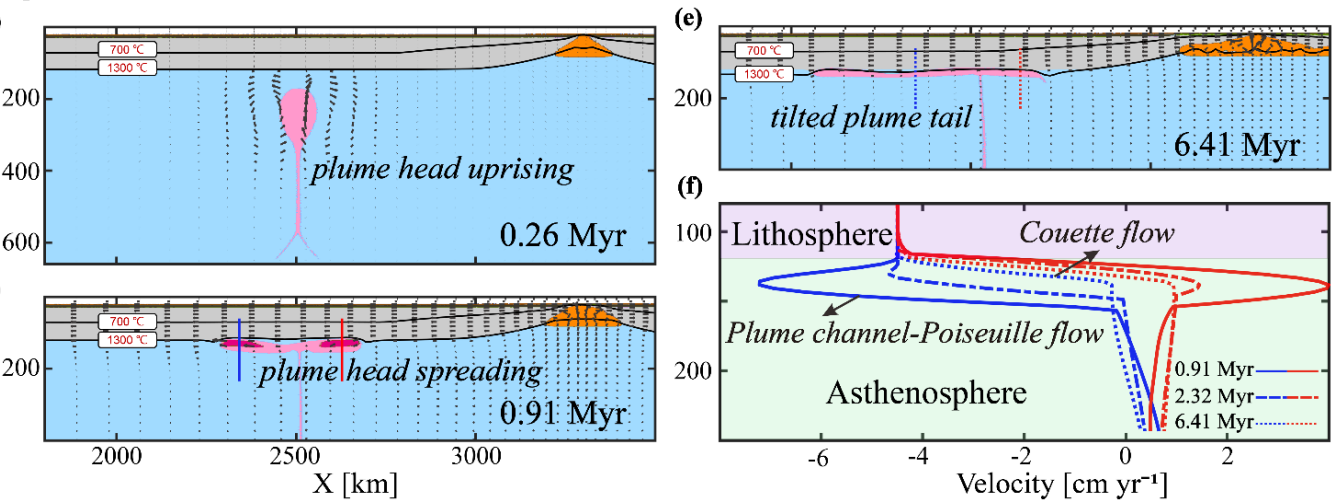

Figure 4. Reference model evolutions of plate-drag on plume flow. The major model parameters employed in this case are: the half spreading rate of $45 \mathrm{~mm} \mathrm{yr}^{-1}$, the plume radius of $100 \mathrm{~km}$, and the off-axis distance of $800 \mathrm{~km}$. (a) topography evolutions along the flow path of selected snapshots. (be) snapshots of reference plate-drag dominated model in compositional domain. Solid, dash and dotted lines are the velocity profiles of plume branches $100 \mathrm{~km}$ aside the plume stem and plot in $\mathrm{f}$. (f) mantle lines, respectively. 

a result, the heat flux at the surface is much lower (Fig. 5f).
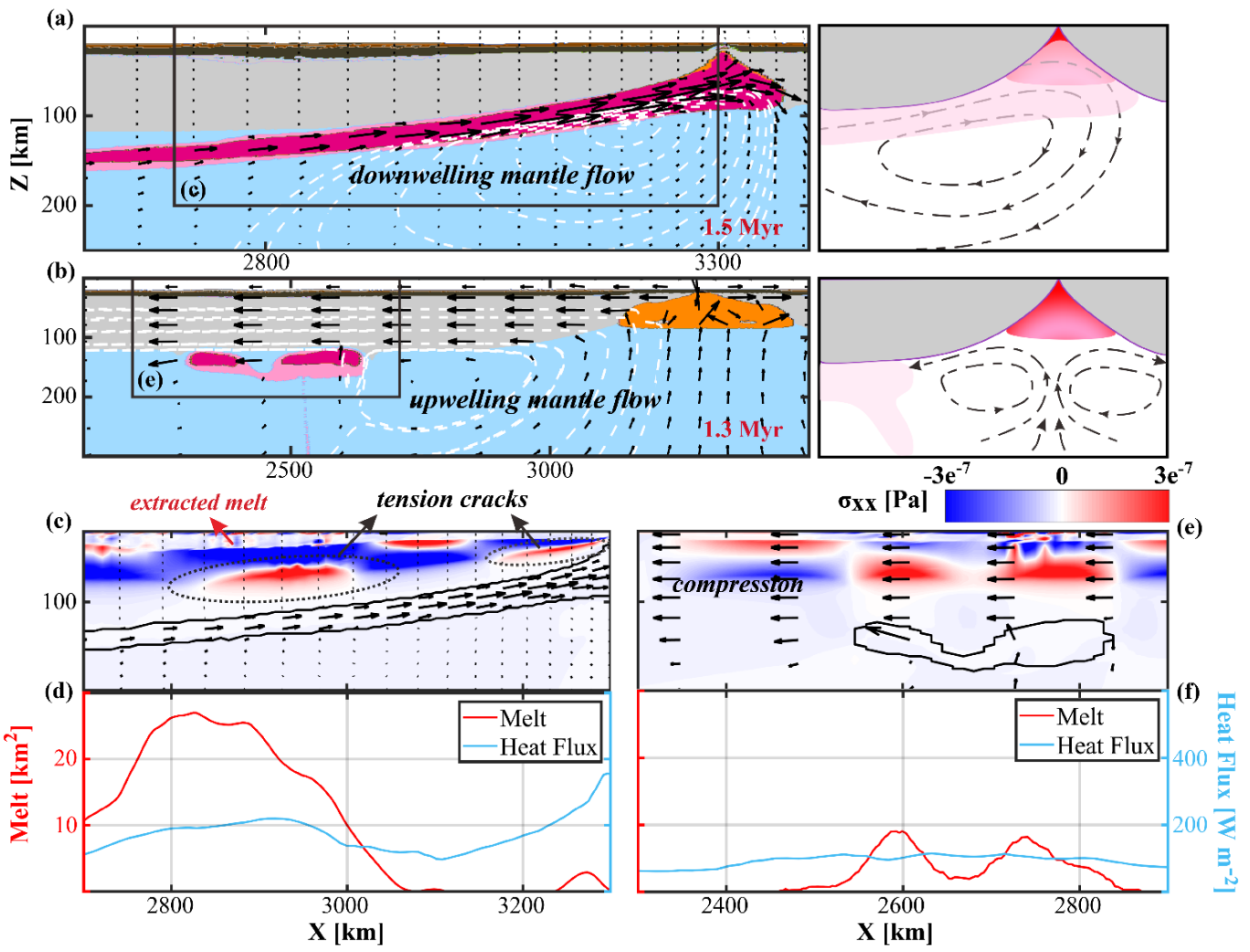

Figure 5. Comparsion between model evolution leading to ridge suction and plate drag mode on mantle plume. (a) Ridge sucks mantle plume with downwelling mantle flow (reference suction dominated model results: Fig.3). (b) Plate drags plume away with upwelling mantle corner flow 
(reference plate drag dominated model results: Fig.4). White dash lines are the streamlines. Schematic cartoons of ridge suction and plate drag pattern plot in the right panels. (c, e) Normal stress along lithosphere of black selected area in (a), (b). (d, f) Volume of extracted basalts and heat flux in overhead lithosphere. Red lines show the extracted basalt volume within oceanic crust, and blue lines refer to the surface heat flux. Bulk of melt extract on the surface through the tensile cracks.

\section{3 ridge suction versus plate drag}

The ridge suction and plate drag are two distinct modes of plume-ridge interaction. The differences between these two types of modes are further demonstrated in terms of mantle flow (Fig. 5) and parameter effects (Figs. 6,7). In the ridge suction dominated models, clockwise mantle flow could form from the plume to the spreading ridge (Fig. 5a). A large amount of molten plume material flows to the spreading ridge and occupies the space underneath the ridge axis. As a consequence to the continuous supply of the plume material, downward mantle flow forms beneath the ridge axis. This flow pattern dramatically differs from that shown in the plate drag dominated models, which show upward mantle flow underneath the ridge axis (Fig. 5b). Mantle corner flows are generated in the plate drag dominated models, which block the plume flow towards the ridge. Such mantle flow blows down the plume tail, and the moving plate carries away the subsequently upwelling plume material. These two distinct modes of plume-ridge interaction (ridge suction vs. plate drag) are controlled by model parameters (Fig. 6). 


\section{Suction fraction}

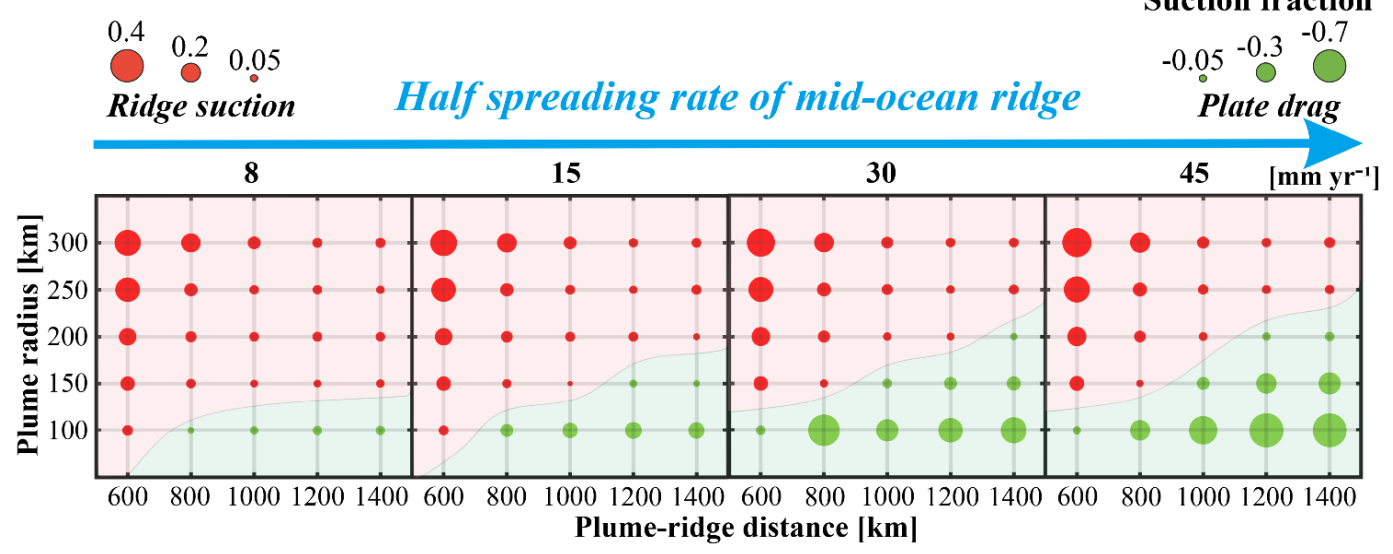

Figure 6. Parameter regime of the contrasting plume-ridge interaction modes. Suction fractions (the ratio of net volume difference between plume material transports ridge-ward and excludes away from ridge, Eq.(10)) at ca.8 Myr after plume head expansion. Each of the circles represents one of the numerical experiments, and sizes refer to the suction fractions. Circles in green represent ridge dragging away the plumes, whereas red circles display plumes are sucked to the ridge axis dominantly.

We have systematically investigated the effect of the three main model parameters (i.e., the spreading rate of the mid-ocean ridge, plume radius and initial off-axis distance of plume) on plumeridge interaction (Fig. 6). We explored half spreading rates of the mid-ocean ridge of 8, 15, 30, and 45

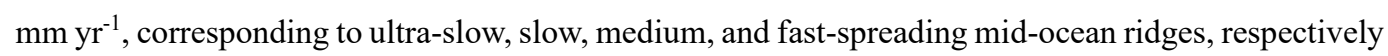
(Gerya, 2012). We varied plume radii in the range of $100 \mathrm{~km}$ to $300 \mathrm{~km}$. Further, the tested off-axis distance ranges from 600 to $1400 \mathrm{~km}$.

Generally, the size of the buoyant plume exerts a major control on plume-ridge interaction. Small plumes tend to be dragged away from the ridge, with typically larger lateral fluxes of the left branch than the right branch of the spreading plume (Figs. 7a-c). As plume dynamic overpressures are small, 

at the base of the plate. This vigorous spreading can overcome plate drag to drive Poiseuille flow in both directions (Fig. 7c). Once the right plume branch approaches the spreading center, it is attracted and further accelerated by ridge suction. The plume tail is also markedly tilted towards the ridge axis more plume material gets entrained by the spreading center.

Plume head stage - positive spreading out
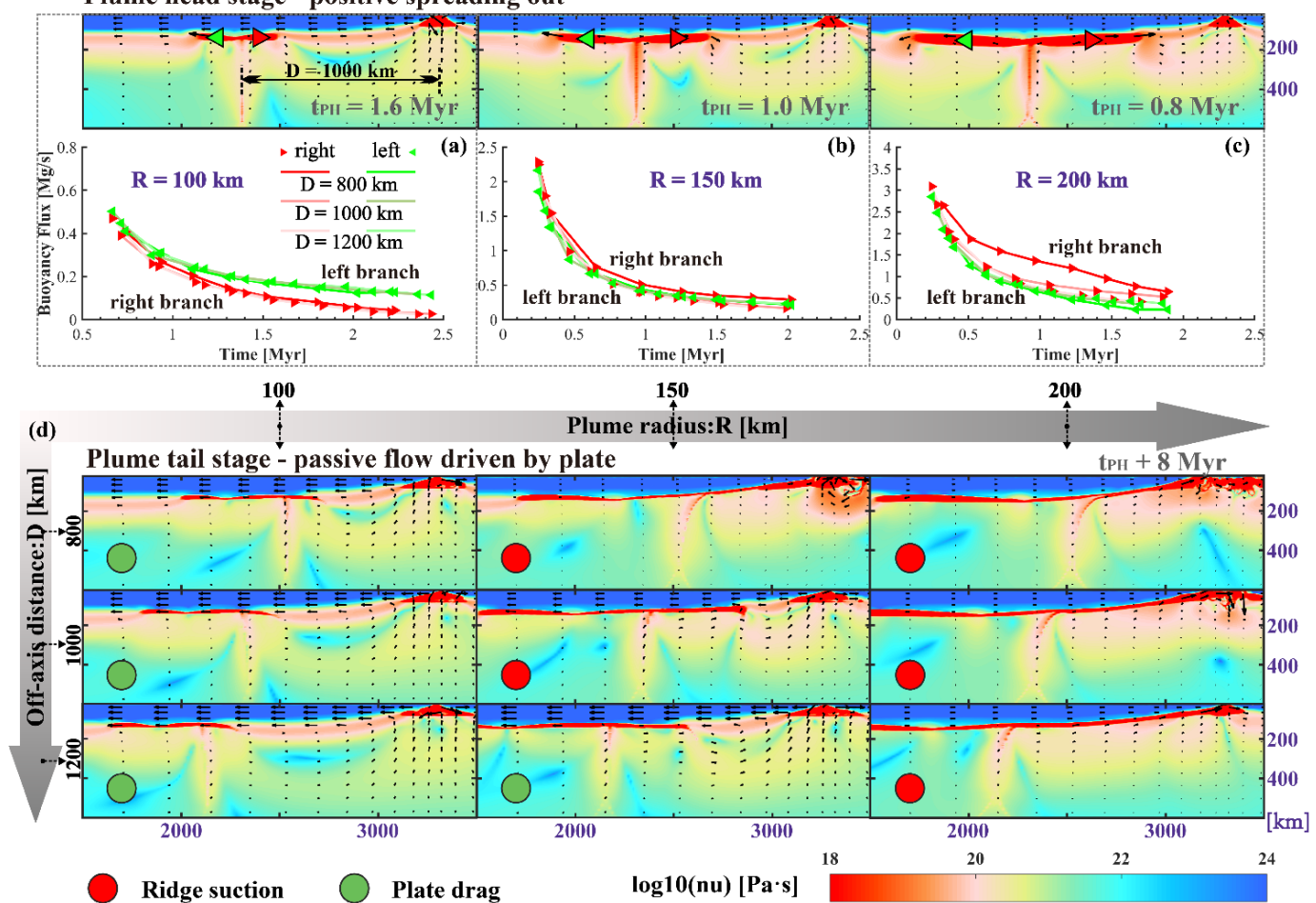

Figure 7. Parameter regime showing ridge suction versus plate drag in the selected parameter space.

(a-c) Time evolution of buoyancy flux and viscosity in spreading plume branches with varied plume 
flux calculation. (d) Viscosity snapshots of models with different plume size, plume-ridge distance at ca.8 Myr after plume head ponding $\left(\mathrm{t}_{\mathrm{PH}}\right)$ beneath the plate are shown. Models with green circle represent plate drag dominated pattern and ridge suction in red.

Moreover, plume-ridge distance also controls the regime of plume-ridge interaction. A plume at large distances spreads similarly with a plume at small distance, but is less likely to get affected by ridge suction (Figs. 7b,d). The dynamic pressure gradient is exactly what drives the flow between the plume and ridge. The larger the plume-ridge distance, the smaller the pressure gredient would be. On the other hand, the difficulty in creating plume-ridge connection in the case may also link to the heat transfer between the cold plate and the hot plume rocks. With gradually cooling from upper plate by heat conduction and diffusion, viscosity of plume increases with the reduction of temperature. Such increasing viscosity slows the plume down, inhibiting the flow to ridge consequently (Fig. 7d). Previous studies indicated that the extra travelling time needed for an additional $200 \mathrm{~km}$ of plume to reach the ridge is roughly equal to the thermal diffusion time for a $20 \mathrm{~km}$ thick, sub-horizontal plume channel cooled from above rigid lithosphere (Kincaid et al., 1996). Hence, for those distant cases, it takes longer time for plume material to reach the ridge, during which the ponding plume head is exhausted and ultimately carried away by the moving plate.

With increasing spreading rate, the effect of plate shearing on plume-lithosphere interaction increases, as quantified by the suction fraction. The suction fraction $\gamma$ (Eq.(10)) is defined as the ratio of plume volume fluxes transported ridgeward and dragged away from the ridge, and a proxy to evaluate the relative strengths of ridge suction and plate drag. We integrated the sucked plume volume flux (right branch), $V_{s p}$, and dragged plume volume flux (left branch), $V_{e p} . V_{p}$ is the total plume 
https://doi.org/10.5194/se-2022-20

Preprint. Discussion started: 16 February 2022

(c) Author(s) 2022. CC BY 4.0 License.

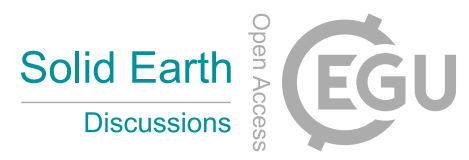

(c) (i)

318 volume flux in the model. Ridge suction is dominant for positive $\gamma$; plate drag is dominant for negative

$319 \gamma$.

$$
\gamma=\left(V_{s p}-V_{e p}\right) / V_{p}
$$

The characteristic suction fractions as a function of our model parameters are shown in Fig. 6.

322

323

324

325

326 


\section{Discussion}

\subsection{Effects of spreading rate on plate drag}

The spreading rate of the mid-ocean ridge affects plume-ridge interaction, and the modeling results show that fast-spreading ridges promote dragging of plumes due to plate friction (Figs. 6, 8a). Here, we further demonstrate the effect of spreading rate on plume motion. Firstly, the calculation of suction fractions $\gamma$ (Eq.(10)) over time shows the switch from dominant ridge suction to dominant plate drag (Fig. 8b). In the early stage (ca.1 Myr), ridge suction plays the dominant role in all these models, mainly due to the active expansion of the plume heads to the low pressure centers underneath the spreading ridges. After a certain time, the suction factors decrease dramatically with the decay of the mantle plume activity, representing the transition from ridge suction to plate drag dominated stage.

The transition from ridge suction (positive $\gamma$ ) to plate drag (negative $\gamma$ ) is mainly determined by the competition between effects of plume spreading (overpressure in the plume-head stage) and plate shearing. The overpressure in the plume head drives plume materials to the lower pressure spreading center, while the moving plate shears plume away. Hence, we quantify the shear force of the overriding oceanic plate on the plume head using an integral approach and the pressure diffenence between plume head and ridge center.

$$
F_{s}=\int \sigma_{x z} d A
$$

Equation (11) is employed to calculate the shear force, where $F_{S}$ is the total shear force the spreading oceanic plate exerts on the plume. $\sigma_{x z}$ is the shear stress on each mantle plume gird cell, $A$ refers to the area of each grid cell. The pressure difference is calculated from the averaged pressure in a $50 \mathrm{~km}$ box of the plume head and ridge center (Fig. 8a). As plume material rises to the lithosphere base, the shear force from the plate increases over time. We find that the integrated shear force between 
the spreading plate and the plume increases significantly as half spreading rate increases (Fig. 8c), indicating larger plate friction force that the fast-spreading plate exerting on the plume head.

Conversely, the spreading of the ridge contributes to the pressure-driven suction of plume materials. During the plume head stage, dynamic pressure of plume rises, and the ridge suction is able to overcome the plate drag, pumping plume to the ridge. However, without plume further supplies, the overpressure difference from the plume head to the spreading center decreases slowly with time (Fig. 8d). The plume branches get cool and their vitality is greatly reduced. As soon as plume push decreases, the suction fraction turns negative (Fig. 8b). More importantly, increasing the spreading rate of ridge generates a smaller overpressure difference. The faster the ridge spreads, the lower the dynamic pressure gradient driving the ridge suction. Thus, strong plate shearing force, combined with small overpressure difference, will significantly suppress the plume-ridge interaction and gradually drag the buoyant plume material away from the ridge. In addition, while all models gradually switch from ridge suction in the plume-head stage to dominant plate drag in the plume-tail stage, the model with fastspreading rate shifts much sooner than that with slow-spreading rate.

(a)

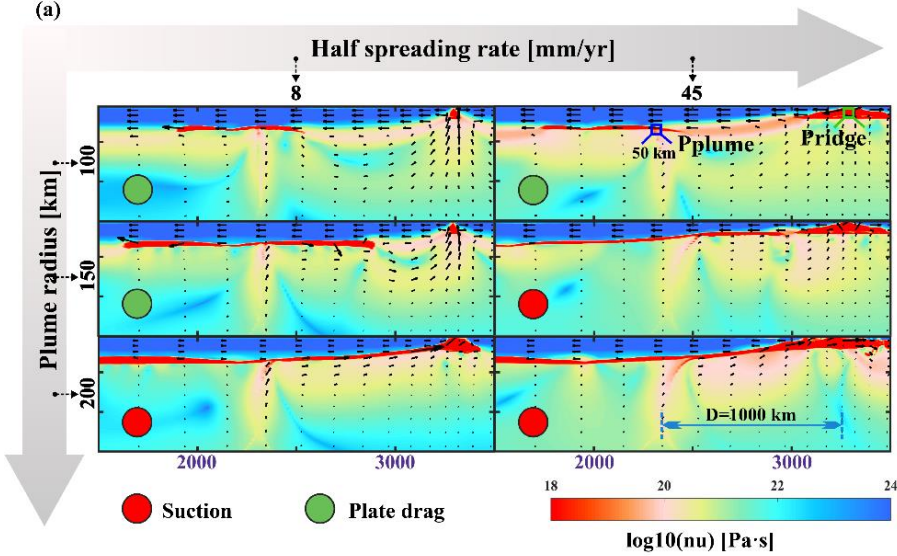

$0.8 \mathrm{~cm} \mathrm{yr}^{-1} 1.5 \mathrm{em} \mathrm{yr}^{-1} 3.0 \mathrm{~cm} \mathrm{yr}^{-1} 4.5 \mathrm{~cm} \mathrm{yr}^{-1}$

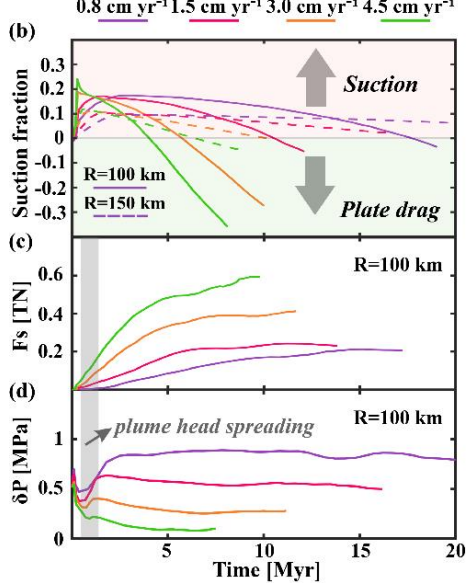

Figure 8. Model results influenced by different half spreading rates. (a) Effect of spreading rate on 
ridge suction verse plate drag. viscosity snapshots are shown. Fast-spreading ridge promote plume dragging. (b) Dynamic evolutions of ridge suction and plate drag on plume, revealed by defined ridge suction fraction (the ratio of net volume difference between plume material transports ridge-ward and excluded away from ridge). (c) Shear force $(F s)$ between moving plate and plume material under different spreading rates. (d) Overpressure difference ( $\delta P$ : Pplume - Pridge) between plume head and ridge center of different half spreading rates models. The overpressure in ridge and plume are the mean dynamic pressure of $50 \times 50 \mathrm{~km}$ box in (a).

\subsection{Plate drag dominated at the East Pacific rise?}

The tested plume size, plume-ridge distance and spreading rates of mid-ocean ridges largely affect the plume-ridge interaction. Natural observations show that, unlike the wide distributed of plume-ridge interactions along the Atlantic and the southwest Indian mid-ocean ridges, there is not much hotspots close to the east Pacific rise (Fig. 9a). A previous study (Jellinek et al., 2003) proposed that fastspreading ridges exert strong ridge suction on plumes and attract the surrounding plumes entirely to the spreading centers from deep mantle (Fig. 1c), which leads to fewer hotspots along the nearby fastspreading ridges. However, based on our modeling results, we propose that fast-spreading ridges are more likely to push away plumes, providing an alternative explanation to the relatively absence of hotspots along the East Pacific Rise. We discuss the possibility of this assumption combined with geological and geophysical observations (Fig. 9).

Firstly, the plate drag effect of fast-spreading ridges on plumes is evidenced by geophysical observations. We locate the positions of the mantle plumes at the core-mantle boundary (CMB) and the associated hot spots on the surface based on the recent study (Jackson et al., 2021). The offset 
between the deep and surface position of plumes is a common feature, indicating the tilt of plumes due to mantle flow. Specifically, a large portion of plumes located in the Atlantic Ocean tilt to the midocean ridges. However, very few plumes in the Pacific Ocean tilt to the mid-ocean ridges, and the majority of plumes move away from the ridges, indicating the significant effect of dragging by the fast-spreading ridges. These indications imply that the plumes are more likely to bend by shallow mantle flows, such as backflow due to plate subduction or ridge spreading. Such observations are consistent with the predictions of plate drag model which well explains the absence of hotspots along the East Pacific rise.

Geochemical studies suggest that mantle plumes, together with interacted MORs, are enriched in light rare earth elements (LREEs) and radiogenic isotopes of $\mathrm{Sr}$ and $\mathrm{Pb}$ but depleted in $\mathrm{Nd}$ isotopes. We find that both the Atlantic and east Pacific Oceans display heterogeneities along the ridge axis (Fig. 9b), indicating the mixture of plume material. However, the Mid-Atlantic ridge seems slightly more heterogeneous than the East Pacific rise in terms of geochemical isotopes. The East Pacific rise is basically characterized as normal oceanic basalt, along which only several regions show composition associated with nearby plumes. This contradicts the view (Jellinek et al., 2003) that mantle plumes are incorporated into the central upwelling underneath the fast-spreading ridges.

Based on our modeling results, the plume-ridge interaction is strongly influenced by plume radius, plume-ridge distance and velocity of the plate. Most of plumes in the Pacific ocean, upwelling from the Pacific super plume, exhibit typical signatures of plume flow away from the MOR, such as swell shapes (e.g., Society, Marquesas and Hawaii; Ballmer et al., 2013; Ballmer et al., 2015; Cheng et al., 2015; Wolfe et al., 2009), and linear volcanic chains (Buff et al., 2021; Clouard and Bonneville, 2005; Jackson et al., 2010). These age-progressive hotspots trails indicate the effects of plate drag on mantle 

plumes under appropriate conditions. In the case of short off-axis distance, there is good evidence of plume-ridge interaction in the southern EPR (Conder et al., 2002; Toomey et al., 2002; Vlastélic and Dosso, 2005). But generally, the rapid movement of plate is not helpful to the ridge suction. Chances are that ridge with high velocity will drag away rather than suck plume strongly. Based on a series of numerical modeling as well as geological and geophysical observations, we predict that mantle plumes in the Pacific Ocean are more likely to be dragged away by the spreading ridge.

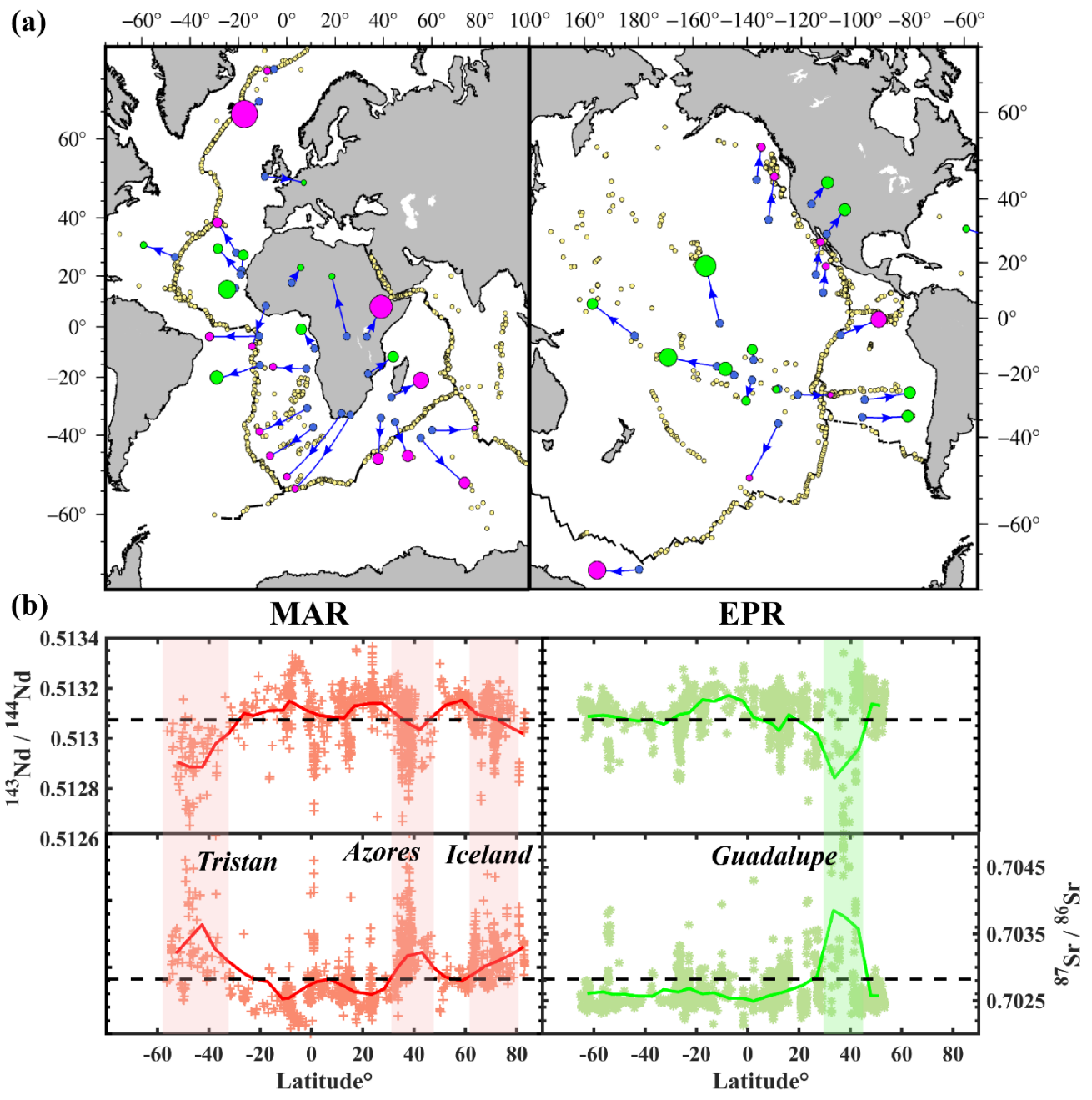


Figure 9. A compilation of hotspots along with spreading ridges in MAR and EPR. (a) Distribution of surface hotspots (circles) together with depth-projected source locations at CMB (blue dots) of the plumes based on (Jackson et al., 2021), using the plume catalogue of (Hoggard et al., 2020). Plumes in magenta circles are mantle plumes sucked by ridges (Ito et al., 2003), and plumes dragged away by ridges are shown as green circles, whose size refers to the plume buoyancy flux. Yellow dots are MORB samples mapped in (b). (b) Plot of radioactive isotopes ratios along ridge MORB samples. The data are downloaded from the PetDB Database (http://portal.earthchem.org/). The colored symbols refer to samples in different mid-ocean ridge. Main hotspots influencing MORBs are labeled with shaded bands. The black dash lines are the mean MORB isotopes ratio from Gale (2013). Red and green lines are the mean ratios of the samples in MAR and EPR, respectively.

\section{Conclusion}

In this study, we explore the evolution of plume-ridge interaction with 2D thermomechanical numerical models. Based on model results, following conclusions are as follows.

(1) Plume-ridge interaction is mainly determined by the competition between effects of plume spreading (overpressure in the plume-head stage) and plate shearing, which is strongly influenced by plume size, plume-ridge distance and the spreading rate of the mid-ocean ridge. The plume size, that is, the plume buoyancy flux, may play a critical role in controlling the connection between the two units, compared with distance and spreading rate.

(2) MORs can not only draw upwelling plumes into spreading center, but plates also push mantle plumes away. Plate-dragged mantle plumes are largely favored by week remote plume and fastspreading ridges, whereas those big mantle plumes are inclined to be sucked into the nearby slow- 
https://doi.org/10.5194/se-2022-20

Preprint. Discussion started: 16 February 2022

(C) Author(s) 2022. CC BY 4.0 License.

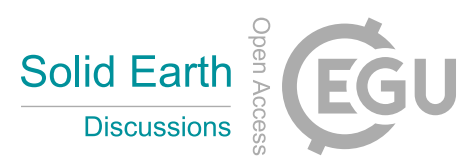

439 spreading MORs.

440 (3) Mantle plumes in the Pacific Ocean are more likely to move away from fast-spreading EPR rather

441 than sucked into the ridge center.

442

443 
https://doi.org/10.5194/se-2022-20

Preprint. Discussion started: 16 February 2022

(c) Author(s) 2022. CC BY 4.0 License.

\section{Code availability}

The source numerical modeling code in this study is available from the corresponding author upon reasonable request.

\section{Data availability}

The data that support the findings of this study are available from the corresponding author upon reasonable request.

\section{Author contribution}

Fengping Pang performed all numerical models, interpreted results and wrote the manuscript. Jie Liao proposed the study, modify the code and contributed to rewriting and scientific discussion. Maxim D. Ballmer contributed with significant help in rewriting and scientific discussion. Lun Li participated in discussion and interpretations. All authors have read and edited draft versions of the paper and have approved the final version.

\section{Competing interest}

The authors declare that they have no conflict of interest.

\section{Acknowledgement}

This research is financially supported by NSFC projects (U1901214, 41974104, 91855208) and Guangdong project 2017ZT07Z066. We are grateful to Prof. Taras Gerya for his long-lasting guidance on our geodynamical modeling. We gratefully acknowledge Hongjian Fang for insightful discussions. 
https://doi.org/10.5194/se-2022-20

Preprint. Discussion started: 16 February 2022

(C) Author(s) 2022. CC BY 4.0 License.

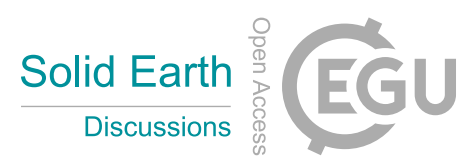

(c) (1)

Numerical simulations were performed on the clusters of National Supercomputer Center in

467 Guangzhou (Tianhe-II).

468 


\section{Reference}

Ballmer, M. D., Ito, G., Wolfe, C. J. and Solomon, S. C.: Double layering of a thermochemical plume in the upper mantle beneath Hawaii, Earth Planet. Sci. Lett., 376, 155-164, doi:10.1016/j.eps1.2013.06.022, 2013.

Ballmer, M. D., Ito, G. and Cheng, C.: Asymmetric dynamical behavior of thermochemical plumes and implications for hawaiian lava composition, Geophys. Monogr. Ser., 208, 35-57, doi:10.1002/9781118872079.ch3, 2015.

Barruol, G., Sigloch, K., Scholz, J. R., Mazzullo, A., Stutzmann, E., Montagner, J. P., Kiselev, S., Fontaine, F. R., Michon, L., Deplus, C. and Dyment, J.: Large-scale flow of Indian Ocean asthenosphere driven by Réunion plume, Nat. Geosci., 12(12), 1043-1049, doi:10.1038/s41561-0190479-3, 2019.

Buff, L., Jackson, M. G., Konrad, K., Konter, J. G., Bizimis, M., Price, A., Rose-Koga, E. F., Blusztajn, J., Koppers, A. A. P. and Herrera, S.: "Missing Links" for the Long-lived Macdonald and Arago Hotspots, South Pacific Ocean, Geology, 49(5), 541-544, doi:10.1130/G48276.1, 2021.

Byerlee, J.: Friction of rocks, Pure Appl. Geophys. PAGEOPH, 116(4-5), 615-626, doi:10.1007/BF00876528, 1978.

Cheng, C., Allen, R. M., Porritt, R. W. and Ballmer, M. D.: Seismic constraints on a double-layered asymmetric whole-mantle plume beneath Hawai'i, Hawaiian Volcanoes From Source to Surf., 1934, doi:10.1002/9781118872079.ch2, 2015.

Clouard, V. and Bonneville, A.: Ages of seamounts, islands, and plateaus on the Pacific plate, Spec. Pap. Geol. Soc. Am., 388, 71-90, doi:10.1130/0-8137-2388-4.71, 2005.

Conder, J. A., Forsyth, D. W. and Parmentier, E. M.: Asthenospheric flow and asymmetry of the East 
Pacific Rise, MELT area, J. Geophys. Res. Solid Earth, 107(B12), ETG 8-1-ETG 8-13, doi:10.1029/2001jb000807, 2002.

Cushman, B., Sinton, J., Ito, G. and Dixon, J. E.: Glass compositions, plume-ridge interaction, and hydrous melting along the Galapagos spreading center, $90.5^{\circ}$ wto $98^{\circ} \mathrm{W}$, Geochemistry, Geophys. Geosystems, 5(8), doi:10.1029/2004GC000709, 2004.

Douglass, J., Schilling, J. G. and Fontignie, D.: Plume-ridge interactions of the Discovery and Shona mantle plumes with the southern Mid-Atlantic Ridge $\left(40^{\circ}-55^{\circ}\right.$ S), J. Geophys. Res. Solid Earth, 104(B2), 2941-2962, doi:10.1029/98jb02642, 1999.

French, S. W. and Romanowicz, B.: Broad plumes rooted at the base of the Earth's mantle beneath major hotspots, Nature, 525(7567), 95-99, doi:10.1038/nature14876, 2015.

Gale, A., Dalton, C. A., Langmuir, C. H., Su, Y. and Schilling, J. G.: The mean composition of ocean ridge basalts, Geochemistry, Geophys. Geosystems, 14(3), 489-518, doi:10.1029/2012GC004334, 2013.

Geissler, W. H., Wintersteller, P., Maia, M., Strack, A., Kammann, J., Eagles, G., Jegen, M., Schloemer, A. and Jokat, W.: Seafloor evidence for pre-shield volcanism above the Tristan da Cunha mantle plume, Nat. Commun., (2020), doi:10.1038/s41467-020-18361-4, 2020.

Gerya, T.: Origin and models of oceanic transform faults, Tectonophysics, 522-523, 34-54, doi:10.1016/j.tecto.2011.07.006, 2012.

Gerya, T. V.: Three-dimensional thermomechanical modeling of oceanic spreading initiation and evolution, Phys. Earth Planet. Inter., 214, 35-52, doi:10.1016/j.pepi.2012.10.007, 2013.

Gerya, T. V. and Yuen, D. A.: Characteristics-based marker-in-cell method with conservative finitedifferences schemes for modeling geological flows with strongly variable transport properties, Phys. 
Earth Planet. Inter., 140(4), 293-318, doi:10.1016/j.pepi.2003.09.006, 2003.

Gerya, T. V. and Yuen, D. A.: Robust characteristics method for modelling multiphase visco-elastoplastic thermo-mechanical problems, Phys. Earth Planet. Inter., 163(1-4), 83-105, doi:10.1016/j.pepi.2007.04.015, 2007. Hoggard, M. J., Parnell-turner, R. and White, N.: Hotspots and mantle plumes revisited: Towards reconciling the mantle heat transfer discrepancy, Earth Planet. Sci. Lett., 542, 116317 , doi:10.1016/j.epsl.2020.116317, 2020.

Ito, G., Lin, J. and Graham, D.: Observational and theoretical studies of the dynamics of mantle plume-mid-ocean ridge interaction, Rev. Geophys., 41(4), doi:10.1029/2002RG000117, 2003. Jackson, M. G., Hart, S. R., Konter, J. G., Koppers, A. A. P., Staudigel, H., Kurz, M. D., Blusztajn, J. and Sinton, J. M.: Samoan hot spot track on a "hot spot highway": Implications for mantle plumes and a deep Samoan mantle source, Geochemistry, Geophys. Geosystems, 11(12), doi:10.1029/2010GC003232, 2010. Jackson, M. G., Becker, T. W., Steinberger, B., Atlantic, P., Atlantic, P. and Pacific, L.: Spatial Characteristics of Recycled and Primordial Reservoirs in the Deep Mantle, Geochemistry, Geophys. Geosystems, 22(3), doi:10.1029/2020GC009525, 2021.

Jellinek, A. M., Gonnermann, H. M. and Richards, M. A.: Plume capture by divergent plate motions: Implications for the distribution of hotspots, geochemistry of mid-ocean ridge basalts, and estimates of the heat flux at the core-mantle boundary, Earth Planet. Sci. Lett., 205(3-4), 361-378, doi:10.1016/S0012-821X(02)01070-1, 2003.

Jiang, Q., Jourdan, F., Olierook, H. K. H., Merle, R. E. and Whittaker, J. M.: Longest continuously erupting large igneous province driven by plume-ridge interaction, Geology, 1-3, 
doi:10.1130/G47850.1, 2020.

Katz, R. F. and Spiegelman, M.: A new parameterization of hydrous mantle melting, , 1-19, doi:10.1029/2002GC000433, 2003.

Kincaid, C., Schilling, J.-G. and Gable, C.: The dynamics of off-axis plume-ridge interaction in the uppermost mantle, Earth Planet. Sci. Lett., 137(1-4), 29-43, doi:10.1016/0012-821X(95)00201-M, 1996.

Koptev, A., Calais, E., Burov, E., Leroy, S. and Gerya, T.: Dual continental rift systems generated by plume-lithosphere interaction, Nat. Geosci., 8(5), 388-392, doi:10.1038/ngeo2401, 2015.

Lénat, J. F., Merle, O. and Lespagnol, L.: La réunion: An example of channeled hot spot plume, J.

Volcanol. Geotherm. Res., 184(1-2), 1-13, doi:10.1016/j.jvolgeores.2008.12.001, 2009.

Li, A. and Detrick, R. S.: Azimuthal anisotropy and phase velocity beneath Iceland: Implication for plume-ridge interaction, Earth Planet. Sci. Lett., 214(1-2), 153-165, doi:10.1016/S0012821X(03)00382-0, 2003.

Mittelstaedt, E., Ito, G. and Behn, M. D.: Mid-ocean ridge jumps associated with hotspot magmatism, Earth Planet. Sci. Lett., 266(3-4), 256-270, doi:10.1016/j.epsl.2007.10.055, 2008.

Mittelstaedt, E., Ito, G. and Van Hunen, J.: Repeat ridge jumps associated with plume-ridge interaction, melt transport, and ridge migration, J. Geophys. Res. Solid Earth, 116(1), 1-20, doi:10.1029/2010JB007504, 2011.

Montelli, R., Nolet, G., Dahlen, F. A., Masters, G., Engdahl, E. R. and Hung, S. H.: Supporting OnlineMaterial Timing, Science, 303(5656), 338-343, doi:10.1126/science.1092485, 2004.

Morgan, W. J.: Convection plumes in the lower mantle, Nature, 230(5288), 42-43, doi:10.1038/230042a0, 1971. 
Müller, R. D., Roest, W. R. and Royer, J.-Y.: Asymmetric sea-floor spreading caused by ridgeplume interactions, Nature, 396(6710), 455-459, doi:10.1038/24850, 1998.

Müller, R. D., Seton, M., Zahirovic, S., Williams, S. E., Matthews, K. J., Wright, N. M., Shephard, G. E., Maloney, K. T., Barnett-Moore, N., Hosseinpour, M., Bower, D. J. and Cannon, J.: Ocean Basin Evolution and Global-Scale Plate Reorganization Events since Pangea Breakup, Annu. Rev. Earth Planet. Sci., 44, 107-138, doi:10.1146/annurev-earth-060115-012211, 2016.

Niu, Y.: Ridge suction drives plume-ridge interactions, , (October), doi:10.13140/2.1.4728.0961, 2014.

Ranalli: Rheology of the Earth, 1995.

Ribe, N. M.: The dynamics of plume-ridge interaction: 2. Off-ridge plumes, , 101, 1996.

Ribe, N. M., Christensen, U. R. and Theißing, J.: The dynamics of plume-ridge interaction, 1: Ridgecentered plumes, Earth Planet. Sci. Lett., 134(1-2), 155-168, doi:10.1016/0012-821X(95)00116-T, 1995.

Sleep, N. H.: Lateral flow and ponding of starting plume material, J. Geophys. Res. Solid Earth, 102(B5), 10001-10012, doi:10.1029/97jb00551, 1997.

Straume, E. O., Gaina, C., Medvedev, S., Hochmuth, K., Gohl, K., Whittaker, J. M., Abdul Fattah, R., Doornenbal, J. C. and Hopper, J. R.: GlobSed: Updated Total Sediment Thickness in the World's Oceans, Geochemistry, Geophys. Geosystems, 20(4), 1756-1772, doi:10.1029/2018GC008115, 2019.

Toomey, D. R., Wilcock, W. S. D., Conder, J. A., Forsyth, D. W., Blundy, J. D., Parmentier, E. M. and Hammond, W. C.: Asymmetric mantle dynamics in the MELT region of the East Pacific Rise, Earth Planet. Sci. Lett., 200(3-4), 287-295, doi:10.1016/S0012-821X(02)00655-6, 2002. 
https://doi.org/10.5194/se-2022-20

Preprint. Discussion started: 16 February 2022

(c) Author(s) 2022. CC BY 4.0 License.

Torsvik, T. H., Smethurst, M. A., Burke, K. and Steinberger, B.: Large igneous provinces generated from the margins of the large low-velocity provinces in the deep mantle, Geophys. J. Int., 167(3), 1447-1460, doi:10.1111/j.1365-246X.2006.03158.x, 2006.

Turcotte, D. and Schubert, G.: Geodynamics, Cambridge University Press., 2014.

Vlastélic, I. and Dosso, L.: Initiation of a plume-ridge interaction in the South Pacific recorded by high-precision $\mathrm{Pb}$ isotopes along Hollister Ridge, Geochemistry, Geophys. Geosystems, 6(5), 1-13, doi:10.1029/2004GC000902, 2005.

Whittaker, J. M., Afonso, J. C., Masterton, S., Müller, R. D., Wessel, P., Williams, S. E. and Seton, M.: Long-term interaction between mid-ocean ridges and mantle plumes, Nat. Geosci., 8(6), doi:10.1038/NGEO2437, 2015.

Wolfe, C. J., Solomon, S. C., Laske, G., Collins, J. A., Detrick, R. S., Orcutt, J. A., Bercovici, D. and Hauri, E. H.: Mantle shear-wave velocity structure beneath the Hawaiian hot spot, Science (80-. )., 326(5958), 1388-1390, doi:10.1126/science.1180165, 2009.

Yang, A. Y., Zhao, T. P., Zhou, M. F. and Deng, X. G.: Isotopically enriched N-MORB: A new geochemical signature of off-axis plume-ridge interaction-A case study at $50^{\circ} 28^{\prime} \mathrm{E}$, Southwest Indian Ridge, J. Geophys. Res. Solid Earth, 122(1), 191-213, doi:10.1002/2016JB013284, 2017. 